\title{
An Open Label Study with Hypertension Resistance and Treatment
}

\author{
Dr. K.Jyothsna \\ Department of Pharmacology, Bhaskar Medical College, Yenkapally (V), Moinabad(M), Ranga Reddy district, \\ Telangana -500075
}

\begin{abstract}
Hypertensive patients after 15-20 years develop hypertension resistance. The blood pressure in these patients is always $150 \mathrm{~mm}$ of $\mathrm{Hg}$ of systolic pressure. These patients regularly use ACEI, CCB and thiazide diuretic. Hypertension resistance definetely not respond to thiazide diuretic. In few patients it progresses to hypertensive complecations like Cerebro Vascular Disease. These patients usually respond to aldosterone receptor blocker $(A R B)$, loop diuretics.

$A C E I=$ Angiotensin converting enzyme,$C C B=$ Calcium channel blocker,$A R B=$ Aldosteron receptor blocker ,$C V D=$ Cerebro vascular disease

Key Words: Hypertension Resistance, cerebro vascular disease, thiazide diuretic
\end{abstract}

\section{Introduction}

Resistance hypertension is a hypertension due to concurrent use of three antihypertensive agents of different classes that doesn't decrease. Ideally one of the three agents should be a diuretic and all agents should be prescribed at optimal dose amounts ${ }^{1}$. Prevalence is unknown but observational and clinical trials suggest it is a common clinical problem. In a recent analysis of National Health and Nutrition Examination Survey (NHANES) participants being treated for hypertension only 53\% were controlled to $140 / 70 \mathrm{~mm}$ of $\mathrm{Hg}$. May of NHANES participants with CKD only $37 \%$ were controlled to $<130 / 80 \mathrm{~mm} \mathrm{Hg}^{2}$. In the Antihypertensive and Lipid-Lowering Treatment to prevent Heart Attack Trail (ALLHAT) often approximately 5 years of follow-up, $27 \%$ of participants were on three or more medication. An elderly, alcoholic, obese, diabetic patient, high baseline blood pressure taking excessive dietary salt ingestion with Chronic kidney disease ${ }^{3}$. On ultra sound examination Left Ventricular Hypertrophy expected in females.

\section{Meterials And Methods}

It is comparative, open labeled, cohort study conducted in regional center, Bhaskar Medical college, yenkapally village, moinabad mandal, Hyderabad, Telagana. It was conducted from jan 2016 to june 2016. It was conducted between two groups of patients one group with ACEI, CCB and Diuretic HTN with 20 patients taken pills 6months period without adverse effects. It was compared with another group with ACEI, calcium channel blocker, without diuretic with HTN with 20 patients. The blood pressure should be $>150 \mathrm{~mm}$ of $\mathrm{Hg}$ of systolic pressure. Blood pressure, blood glucose levels, serum potassium levels should be measured before and after treatment. Paired t-test should be measured.

\section{Results}

Patients are taken as 3 groups one at the time of beginning of study, another group at 3 months, 6months, Paired t-test perfomed, p- value taken as acceptable.

\begin{tabular}{|c|c|c|c|c|}
\hline Parameter & $\begin{array}{l}\text { Beginning } \\
\text { Mean } \pm \text { SD }\end{array}$ & $\begin{array}{l}\text { ACEI+CCB+diuretic }+ \\
\text { ARB Mean } \pm \text { SD }\end{array}$ & $\begin{array}{l}\text { ACEI+CCB+diuretic } \\
\text { Mean } \pm \text { SD }\end{array}$ & p-value \\
\hline $\begin{array}{l}\text { Number of } \\
\text { patients }\end{array}$ & 40 & 20 & 20 & \\
\hline Blood Pressure & $115 \pm 5 \mathrm{~mm}$ of $\mathrm{Hg}$ & $107 \pm 4 \mathrm{~mm}$ of $\mathrm{Hg}$ & $111 \pm 5 \mathrm{~mm}$ of $\mathrm{Hg}$ & $0.05^{*}$ \\
\hline Fever & $98.6^{0} \mathrm{~F}$ & $98.6^{0} \mathrm{~F}$ & $98.6^{0} \mathrm{~F}$ & \\
\hline Fasting blood glucose & $107 \mathrm{mg} / \mathrm{dl}$ & $110 \mathrm{mg} / \mathrm{dl}$ & $115 \mathrm{mg} / \mathrm{dl}$ & $0.02^{*}$ \\
\hline Serum $\mathrm{K}^{+}$levels & $3.5 \mathrm{mg} / \mathrm{dl}$ & $3.8 \mathrm{mg} / \mathrm{dl}$ & $3.2 \mathrm{mg} / \mathrm{dl}$ & $0.05^{*}$ \\
\hline
\end{tabular}

Table 1: *p.value $<0.05$ is acceptable 


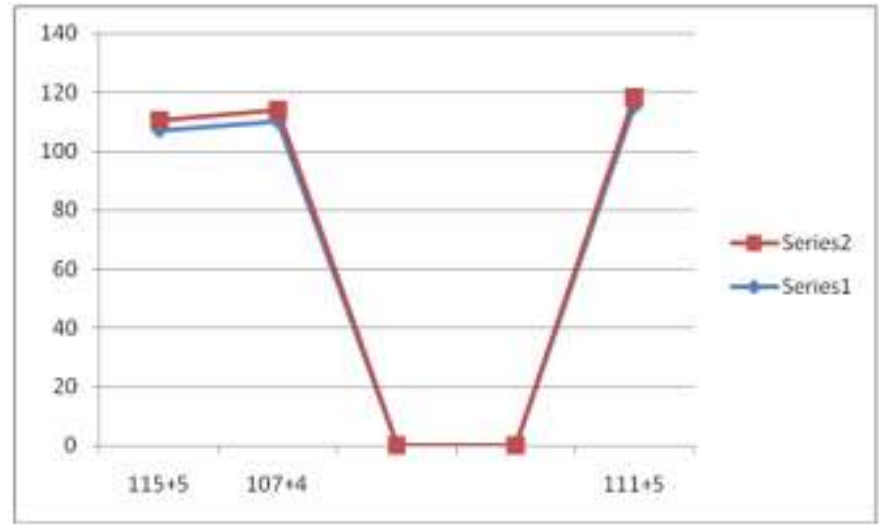

Fig.1

\section{Discussion}

High BP in childhood had been considered a risk factor for hypertension in early adulthood. However, primary (essential) hypertension is now identifiable in children and adolescents ${ }^{4}$. Primary hypertension in childhood is usually characterized by mild or Stage 1 hypertension and is often associated with a positive family history of hypertension or cardiovascular disease (CVD) ${ }^{5}$. Children and adolescents with primary hypertension are frequently overweight ${ }^{6}$. Data on healthy adolescents obtained in school healthscreening programs demonstrate that the prevalence of hypertension increases progressively with increasing body mass index (BMI), and hypertension is detectable in approximately 30 percent of overweight children (BMI >95th percentile) $)^{7}$. Overweight and high BP are also components of the hypertension resistance and a condition of multiple metabolic risk factors for CVD as well as for type 2 diabetes $^{8}$.

Sleep disorders, including sleep apnea, are associated with hypertension, coronary artery disease, heart failure, and stroke in adults. Although limited data are available, they suggest an association of sleep-disordered breathing and higher BP. This addresses the family history of hypertension, diabetes, obesity, sleep apnea, renal disease, other CVD (hyperlipidemia, stroke), and familial endocrinopathies ${ }^{9}$.

The patient with resistance hypertension showed high blood pressure (>150/85 $\mathrm{mm}$ of $\mathrm{Hg}$ ) and resistance to ACEI, CCB and thiazid diuretic. These patients were better responded to fourth drug ARB. Hence these patients are better responding to ARB and Loop diuretics along with ACEI, CCB and diuretic ${ }^{10}$.

\section{Conclussion}

Hypertension resistance patients are better responding to four drug regimen ACEI, CCB, diuretic and ARB. The occarence CVD complications decreased in elderly people.

$\mathrm{ACEI}=$ Angiotensin converting enzyme, $\mathrm{CCB}=$ Calcium channel blocker, $\mathrm{ARB}=$ Aldosteron receptor blocker , $\mathrm{CVD}=$ Cerebro vascular disease

\section{Aknowledgement}

It is thanks to given opportunity to conduct study in Bhaskar Medical College. It was thanks to has given great opportunity to conduct and providing clinical material especially for staff.

\section{References}

[1]. Prineas RJ, Jacobs D. Quality of Korotkoff sounds: Bell vs diaphragm, cubital fossa vs brachial artery. Prev Med 1983;12:715-9.

[2]. Londe S, Klitzner TS. Auscultatory blood pressure measurement - effect of pressure on the head of the stethoscope. West J Med 1984;141:193-5.

[3]. Prineas RJ. Blood pressure in children and adolescents. In: Bulpitt CJ, ed. Epidemiology of hypertension. New York: Elsevier; 2000, 86-105.

[4]. Mourad A, Carney S, Gillies A, Jones B, Nanra R, Trevillian P. Arm position and blood pressure: A risk factor for hypertension? J Hum Hypertens 2003;17:389-95.

[5]. Netea RT, Lenders JW, Smits P, Thien T. Both body and arm position significantly influence blood pressure measurement. J Hum Hypertens 2003;17:459-62.

[6]. Gomez-Marin O, Prineas RJ, Rastam L. Cuff bladder width and blood pressure measurement in children and adolescents. J Hypertens 1992;10:1235-41.

[7]. Prineas RJ. Measurement of blood pressure in the obese. Ann Epidemiol 1991;1:321-36.

[8]. Jones DW, Appel LJ, Sheps SG, Roccella EJ, Lenfant C. Measuring blood pressure accurately: New and persistent challenges. JAMA 2003;289:1027-30.

[9]. Canzanello VJ, Jensen PL, Schwartz GL. Are aneroid sphygmomanometers accurate in hospital and clinic settings? Arch Intern Med 2001;161:729-31.

[10]. Butani L, Morgenstern BZ. Are pitfalls of oxcillometric blood pressure measurements preventable in children? Pediatr Nephrol 2003; 18:313-8 